\title{
A EXPERIÊNCIA NAS AULAS DE ALEMÃO COMO LÍNGUA ESTRANGEIRA NO CONTEXTO BILÍNGÜE
}

Lucía Elena ALVAREZ

\section{Resumo}

Tendo em vista a exigência cada vez maior de dominar duas ou mais línguas tanto no mercado de trabalho quanto no contexto acadêmico, é importante ver de que maneira o ensino dessas línguas estrangeiras modernas (LEM) se dá e de que maneira ele envolve os seus sujeitos. Assim, pretendo, neste relato de sala de aula, discorrer sobre a relação entre os conceitos de linguagem e cultura, acrescentando a eles o conceito de experiência, apresentado primeiramente por Walter Benjamin e que parece estar no seu contexto correto dentro de uma sala de aula. Num segundo momento, descrevo uma experiência de observação de aulas que tive no contexto do ensino de alemão como língua estrangeira, fazendo propostas de mudanças que envolvam essas teorizações de maneira mais completa na prática de sala de aula.

Palavras-chave: linguagem, experiência, cultura, ensino de LEM

\section{A questão da experiência}

O ensino de LEM coloca um elemento central de uma cultura estrangeira frente aos alunos e, para didatizar o processo de ensino-aprendizagem de cada língua, a Escola, como entidade maior, criou divisões e objetivos para cada momento do aprendizado. Dessa organização e padronização do aprendizado participam vários elementos, como o livro didático, os objetivos trimestrais, as provas, o currículo e os planos de ensino. Apesar de todo esse aparato formal que envolve o ensino de LEM e também o de todas as outras disciplinas em uma escola, o que acontece dentro de sala de aula e, principalmente, a experiência de cada aluno nesse contexto, dependem de coisas bastante mais subjetivas, como, por exemplo, as nuances que o professor dá aos textos lidos ou as atividades extra que ele propõe. No limite, a experiência com uma 
outra língua depende em grande parte da atuação do professor e de sua interação com a turma em que está inserido. Nesse sentido, parece-me de vital importância levar em conta o conceito de experiência proposto por Jorge Larrosa em Educação e Linguagem depois de Babel e baseado em críticas literárias de Walter Benjamin, da escola de Frankfurt, pois se considerarmos os desdobramentos que essa definição pode ter, chegaremos à conclusão de que um dos mais profícuos e belos espaços que se tem para o desenvolvimento de uma experiência multicultural limítrofe - no sentido de quebrar as barreiras do multiculturalismo e possibilitar a geração de indivíduos pensantes e críticos quanto à sua formação cultural - são as brechas que se criam dentro do decorrer de uma aula. Falo isso considerando a realidade de muitos dos professores de LEM, que trabalham com poucas aulas por semana, com um currículo que faz com que haja pouco tempo para cada "tópico" a ser visto e com um livro didático que acaba tomando boa parte de seu tempo, tornando-se o objetivo em si da aula em vez de ser apenas um guia. Além disso, é necessário considerar que muitas vezes esses mesmos livros didáticos representam uma visão de linguagem desvinculada da noção de cultura, o que dificulta a costura entre a LEM e a primeira língua do aluno em seu processo de aprendizagem.

Isto posto, acredito que uma das possíveis maneiras de intervir positivamente na realidade das aulas de LEM seja por meio do olhar etnográfico, que nos permite fazer construções teóricas pontuais, vinculadas à realidade. Gostaria, para isso, de relatar uma experiência de observação que tive em uma escola bilíngue português-alemão no sul do Brasil, fazendo sugestões do que poderia ser mudado nas aulas observadas, para voltar a vincular linguagem e cultura, permitindo assim, uma experiência de vivência cultural ao aluno. Antes disso, porém, faz-se necessário esclarecer o cenário teórico em que pretendo envolver a ação pedagógica na aula de LEM.

\section{Cultura}

Vivemos, há alguns anos, fixados, obstinados por cultura. Digo isso partindo do meio em que me encontro inserida, uma vez que trabalhando, há um certo tempo, em uma escola bilingue cujo público maior são famílias das classes média e média-alta, percebo que, principalmente dentro da classe média brasileira, é notável a procura por cursos de línguas para crianças (cada vez mais novas); a diversidade cultural e sua 
aceitação, pelo menos em um certo tipo de discurso, devem ser o objetivo maior da educação. Por outro lado, fala-se muito de tolerância. Tolerância religiosa, étnica, sexual, em todos os campos da vida. A falta de conceitualização do que é cultura, para ficar dentro do escopo deste trabalho, impede que as pessoas se dêem conta de que estão em meio a um fogo cruzado: como é que se pode crer que o contato com outras culturas trará enriquecimento se o objetivo que se tem para esse mesmo contato é a tolerância, que no limite significa conviver pacificamente, sem envolvimentos reais ou conflitos? Há dois pilares fundamentais sobre os quais se baseia a atual esterilidade que permeia o contato entre as culturas: uma noção pobre de cultura, muito ligada aos Estados Nacionais e suas “características típicas” - quando não confundida com a Cultura, com c maiúsculo, que só pode ser encontrada em museus, bibliotecas e cinemas cult; e a tendência ao politicamente correto, que, apesar de todas as evidências contrárias à possibilidade de tal projeto, se engaja em evitar conflitos, oriundos justamente das diferenças.

Para trazer mais clareza ao conceito de cultura que é aqui defendido e usado, faz-se necessário expor algumas das idéias que representam o estado atual da discussão, para então mostrar a que ponto se deseja chegar, uma vez que o conceito proposto não descreve/condiz com a realidade em que vivemos, mas tenta, em um movimento dialógico, modificar essa realidade, na inacabável tarefa de aproximar o real ao ideal.

No segundo capítulo de A Idéia de Cultura, o filósofo e crítico literário Terry Eagleton afirma que estamos presos, neste momento, entre "uma noção de cultura debilitantemente ampla e outra desconfortavelmente rígida, e que nossa necessidade mais urgente nessa área é ir além de ambas”. Essa necessidade de transgressão de conceitos vigentes mostra-se em consonância com o breve histórico dos conceitos de cultura apresentado pelo filósofo alemão Wolfgang Welsch, que ao afirmar que os conceitos de interculturalidade e multiculturalidade, atualmente tão em voga, partem do mesmo princípio de cultura de Johann Gottfried Herder, do fim do séc. XVIII, acaba por evidenciar a grande quebra de paradigmas que está diante de nós. Segundo Welsch, o conceito de cultura apresentado por Herder é unificatório, na medida em que a cultura molda a vida e as ações dos indivíduos nela inseridos, tornando assim todo ato uma expressão da cultura; ligado ao conceito de povo, uma vez que cada cultura representa a “flor” do povo em questão; e separatório, no sentido que, ao delimitar muito 
concretamente o que é uma cultura, impede que esta venha a se misturar a outra. Essas mesmas três características continuam presentes quando se fala de interculturalidade e multiculturalidade, já que a idéia de ter que encontrar meios de conciliar ou criar canais entre as culturas se origina justamente de uma visão das culturas como esferas isoladas, que, mesmo tendo algumas coisas “universais” em comum, só podem ignorar-se mutuamente ou colidir, criando conflitos.

Considerando estas afirmações tão contundentes e voltando à afirmação de Eagleton de que é preciso encontrar uma definição que vá além das duas dificuldades que se tem atualmente, gostaria de propor o uso de um dos muitos conceitos de cultura formulados por Raymond Williams, expoente dos Estudos Culturais britânicos, que é o da cultura como uma estrutura de sentimento. Para ele, estrutura de sentimento é "o resultado vivo particular de todos os elementos na organização geral de uma sociedade” e, desdobrando isso para os fins aqui objetivados, isso pode nos levar a uma definição interessante, que quebra com a noção de esferas vista em Herder: Williams permite, colocando o sentimento como algo essencial da cultura, que se tenha uma noção dialógica dela, em que experiências individuais são, por um lado, guiadas pelo coletivo mas, por outro, se agregam a esse coletivo modificando-o. Para mais além do individual ou subjetivo, essa definição não desconsidera a dimensão material, uma vez que os elementos na organização geral de uma sociedade também incluem as condições sócioeconômicas, históricas e políticas dadas.

Situando a definição acima no contexto da observação feita na escola, fica claro que a partir do momento em que se está numa escola bilingue e - principalmente bicultural, o sentimento passa a povoar uma grande parcela do que é a cultura estrangeira, porque os elementos na organização geral daquela sociedade (a sociedade falante da LEM que se aprende) passam a estar inseridos nos elementos na organização geral da própria sociedade (a do aluno, que ele crê conhecer muito bem), misturando-se e criando, possivelmente, elementos que não chegam a existir nem em uma nem na outra sociedade. Assim, fica evidente que a educação envolvendo mais de uma cultura precisa acontecer por meio de vivências de encontros e desencontros com as regiões limítrofes das culturas, os seus pontos de tangência e suas diferenças mais crassas, para sensibilizar e permitir que o indivíduo sinta o que é seu e o que ainda é só do outro, possibilitando assim confrontos reais entre pessoas, e não idealizações, baseadas em 
datas comemorativas, estereótipos e relativizações dessas diferenças tão concretas entre a cultura "brasileira” e a “alemã”, por exemplo.

\section{Linguagem}

Após haver situado o meu leitor em relação ao conceito de cultura do qual parto para fazer as minhas colocações referentes à pratica de ensino de LEM no Brasil atualmente, acredito que fazer o mesmo tipo de ambientação no que se refere à linguagem seja bastante mais simples, uma vez que se parto de um pressuposto dialógico de cultura para observá-la, seria incoerente não aplicar o mesmo pressuposto à linguagem. Em Marxismo e Filosofia da Linguagem, Mikhail Bakhtin faz uma crítica aos "métodos de reflexão linguística que levam à postulação da língua como sistema de formas normativas”, situando-os como engendrados pela tradição filológica de abordagem das línguas mortas. É interessante notar que para ele toda a pesquisa em torno da linguagem sempre se fundamentou no estudo filológico de línguas estrangeiras, pois esse tipo de normatização, estruturalização, dissecação da língua que hoje em dia vemos como parte predominante até das aulas de língua materna (leia-se: gramática), não faz sentido quando se fala de linguagem em uso. Assim, temos um método que, aplicado à pesquisa de inscrições em línguas mortas, faz todo sentido, uma vez que ali realmente não existe mais um diálogo sincrônico. Houve, porém, um deslocamento desse método para o estudo de línguas vivas, em uso, e é justamente com isso que Bakhtin tenta romper ao dizer que "na prática viva da língua, a consciência linguística do locutor e do receptor nada tem a ver com um sistema abstrato de formas normativas, mas apenas com a linguagem no sentido de conjunto dos contextos possíveis de uso de cada forma particular”.

Acredito que hoje em dia, 80 anos passados da primeira edição dessa obra, a situação tenha se modificado em algumas frentes. No caso das aulas de língua materna, dar esse salto é uma questão simplesmente de realismo. Como as crianças chegam à escola já falando a língua que usam para se comunicar na maior parte do tempo, trata-se de uma questão de conscientização do uso, de um trabalho com gêneros textuais (orais e escritos), de apresentar um viés mais rico de linguagem para esses alunos, ensinandolhes, por um lado, a se adequar aos tais contextos possíveis do uso das formas e por 
outro lado, a criar a língua de uma maneira mais consciente, utilizando-se, por que não, entre outras coisas, de análises filológicas da própria língua. No caso do ensino de LEM, porém, a dificuldade de aproximação com o estrangeiro ainda persiste, criando espaços para que a necessidade tão humana de sistematizar para sentir segurança se imponha. Falta neste campo, ainda, dar-se conta claramente de que, por mais que não seja a língua que aprendemos a falar com os nossos pais e que usamos diariamente tanto para pedir pão na padaria quanto para discutir sobre preferências musicais, a LEM em questão, é viva, e nossa forma de aproximação precisa partir disso para ser bem sucedida. Assim, precisa-se mostrar ao aluno que a língua que ele está aprendendo - ou que, muitas vezes, se quer que ele aprenda - além de estar viva, permite que ele se coloque como indivíduo nela.

\section{Cultura-linguagem}

Partindo dos conceitos acima expostos, gostaria agora de uni-los, mostrando que um dos maiores erros cometidos nas aulas de LEM é justamente tratá-los separadamente. Vale aqui citar Bakhtin novamente, em crítica a Ferdinand de Saussure: “A separação da língua de seu conteúdo ideológico constitui um dos erros mais grosseiros do objetivismo abstrato”. Em seu contexto, Bakhtin fez essa afirmação sem necessariamente levar em conta uma conceituação de cultura; mas dentro do cenário traçado neste relato, a transposição dessa afirmação para a discussão sobre cultura se faz absolutamente necessária. É, também, importante voltar a citar Williams, que em Cultura e Sociedade mostra o alcance de uma cultura "como geralmente proporcional à área de disseminação de uma linguagem”.

Para estabelecer o diálogo "unificatório" entre os dois conceitos, o mais apropriado será discorrer primeiramente sobre cultura em Williams, pois uma das confusões que sua afirmação pode vir a causar, é a de dar a impressão de que ele está aderindo a uma visão nacionalista de cultura, uma vez que a coloca em relação direta com a área. Pensando, porém, em toda a evolução midiática da qual fomos e somos testemunhas, é indispensável considerar a Internet, o cinema, a literatura e tantos outros meios como áreas em que pessoas, possivelmente de regiões completamente diferentes do globo terrestre se relacionam com intensidades antes só imagináveis em um convívio 
presencial. Tendo aberto essa possibilidade, o que Williams afirma se torna extremamente fértil para o campo aqui proposto, uma vez que não fala de língua, mas de linguagem, o que evidencia uma porta aberta em relação às teorizações de Bakhtin. Se para Bakhtin, por outro lado, a linguagem é composta dos contextos em que é utilizada e ela não pode ser descrita se não nas áreas, justamente, de abrangência da cultura, temos que cultura e linguagem são a mesma coisa, pois é o uso de linguagem, isto é, o discurso, que possibilita a expressão de sentimentos e a verbalização das condições materiais dadas, gerando a cultura e sendo modificada por ela a cada momento.

Tendo a noção de cultura-linguagem em mente, quero ainda ressaltar, em relação a ela, que não pretendo propor uma relativização total das singularidades regionais nem desconsiderar completamente a possibilidade de culturas nacionais, pois justamente por ser tão forte, a globalização que vivemos cria também espaços de resistência, que ligando-se a esses últimos conceitos, acabam concretizando-as. Interessa-me aqui lançar um olhar coerente sobre o ensino de LEM, mostrando que não é necessário nem útil separar o ensino da língua, muitas vezes vista como estrutura, da cultura que envolve seus falantes, muitas vezes vista como Cultura. Defendo, assim, que, ao tratar a língua como texto ideológico e simbólico, se está tratando, automaticamente, de cultura.

\section{Experiência}

Para falar de experiência no contexto do ensino de LEM, é importante, antes de partir para a prática, diferenciar o conceito aqui utilizado do significado corrente da palavra tanto no discurso pedagógico quanto fora dele. Jorge Larrosa, em Linguagem e Educação depois de Babel, escreve precisamente sobre a ausência da experiência em nossas vidas e, principalmente, cada vez mais no contexto da escola. Para ele, a experiência é o envolvimento real com alguma coisa, um envolvimento que envolve riscos e passividade - aqui no sentido de deixar os acontecimentos fluírem dentro de nós, não no sentido de aceitar uma dimensão monológica do ocorrido. Experiência não é o que acontece à nossa volta, mas o que nos acontece, o que nos toca e modifica. Existem, porém, na sociedade em que vivemos, guiada pelas grandes mudanças midiáticas ocorridas nas últimas décadas, alguns fatores que impossibilitam, cada vez 
mais, o acontecimento de experiências. São eles 1) o excesso de informação, 2) o excesso de opinião, 3) a falta de tempo e 4) o excesso de trabalho. Vejo no segundo ponto citado um estranho exagero do dialogismo bakhtiniano no discurso pedagógico: cada vez mais entendemos “compreensão de texto" como captar as informações contidas no texto lido e dar, para colocar-se como sujeito, sua opinião sobre ele. Não somos mais capazes de ficar em silêncio e viver o que está no texto; precisamos nos envolver ativamente. Não se trata aqui de afirmar que Bakhtin teria proposto esse tipo de tratamento ao texto; trata-se de uma crítica à leitura de Bakhtin feita por um certo tipo de pedagogo e professor de línguas. Também não é o caso levar em conta uma dimensão imanente do texto; pois uma vez que o texto é escrito por alguém, ele tem, mesmo que implicitamente, um ponto de partida e uma expectativa de um certo leitor. Isso quer dizer que, mesmo que isso não venha nunca a ser explicitado no texto, ele representa uma visão de mundo que, ao ser tematizada e tratado com profundidade, poderia permitir experiências ricas ao leitor por meio do envolvimento real com o mundo do outro. Assim, essa necessidade do ativo, do trabalho, do envolvimento visível e mensurável é que impede a experiência, que é justamente o que permite o real aprendizado de uma língua e de qualquer outra coisa.

Sei que temos pouco tempo, que os “conteúdos” são muitos, que as exigências dos pais de escolas particulares são altas. Mas não podemos nos deixar guiar por essas condições dadas para tornar sua satisfação o fim da ação pedagógica. Se é por meio da repetição que se aprende, então esta deve ter seu lugar. Se é por meio do silêncio e da reflexão - e aqui vale colocar que o objetivo da reflexão não é a opinião - que se interiorizam acontecimentos externos, estes também devem encontrar espaço dentro da escola. Parece-me, neste ponto, conveniente, falar da experiência de Walter Benjamin, que em muitos pontos de suas críticas deu ênfase a esse conceito (Erfahrung). Em um curto escrito sobre a história do brinquedo (Kulturgeschichte des Spielzeugs), ele fala sobre os brinquedos e sua produção na época em que ainda não existia um mercado específico para esses produtos: Os brinquedos eram cheios de detalhes e beleza, eram pequenos objetos, que junto com outros da mesma sorte enchiam as estantes das crianças e seus pais. Depois, com a descoberta de que fazer brinquedos poderia ser um trabalho lucrativo, não mais uma atividade para os momentos de ócio dentro de uma oficina, os brinquedos começaram a se tornar cada vez maiores e realistas, misturando 
materiais e enchendo, cada vez mais, as crianças de informações. Assim, foi-se esquecendo, pouco a pouco, que a criança brinca com os brinquedos porque quer dar concretude à sua imaginação, não porque quer imitar a realidade de maneira cada vez mais bem sucedida. Esqueceu-se que a imitação - tanto da realidade, quanto da imaginação infantil - está na brincadeira e não no brinquedo em si.

Transpondo isso para o contexto educativo, temos livros didáticos cada vez mais cheios de imagens; planos de aula cada vez mais detalhados, que tentam prever as respostas dos alunos a cada atividade proposta; atividades específicas para cada área do aprendizado da língua (vocabulário, gramática, fonética) etc. Esquecemos que boa parte do envolvimento com o aprendizado deve partir do aluno.

Nesse sentido, quero propor dar mais espaço e tempo ao aluno, sem cobrar dele opiniões ou grandes produções trabalhosas, mas envolvimento. Com isso, não sugiro o fim do planejamento das aulas, mas um planejamento menos previsível, menos mensurável, mais amplo no sentido de, além de mostrar cultura-linguagem como um todo, aceitar o aluno como um todo, capaz, ainda que remotamente, de experienciar.

\section{A Observação}

Neste relato vou me restringir a fazer o narração de uma curta sequência de aulas (quatro aulas de 45 minutos), todas referentes ao mesmo assunto, contando primeiramente como foram as aulas que assisti e, depois, como seria uma possível proposta de aulas que respeita as teorizações acima apresentadas, atingindo os mesmos objetivos e tratando dos mesmos gêneros textuais presentes no tópico da unidade 7 do livro didático Wer? Wie? Was? Mega 2 da editora Gilde Verlag, que trata de "música e algo mais”. Para situar melhor o leitor, me parece de vital importância mostrar as páginas do livro que foram usadas nesse período, uma vez que o professor seguiu quase que estritamente o conteúdo e as atividades propostas. Assim, comentários sobre elas serão inseridos no texto de acordo com o seu uso nas aulas, seguidos de uma imagem reduzida da mesma página.

$\mathrm{Na}$ primeira vez em que entrei na sala de aula junto com o professor, fui apresentada brevemente e sentei-me numa cadeira no canto da sala, para poder ter um olhar mais amplo sobre tudo o que ocorria. Nesse dia, ele começou a sua aula 
escrevendo no quadro o que seria feito. Nessa lista apareciam primordialmente páginas do livro com as atividades que estavam planejadas. No fim da lista estava escrito “Spiel” (jogo, em alemão). Depois da lista, o professor pediu às crianças, em sua maioria um pouco agitadas - talvez por conta da idade: 11 anos, em pleno início de puberdade -, que abrissem o livro-texto na página 74.

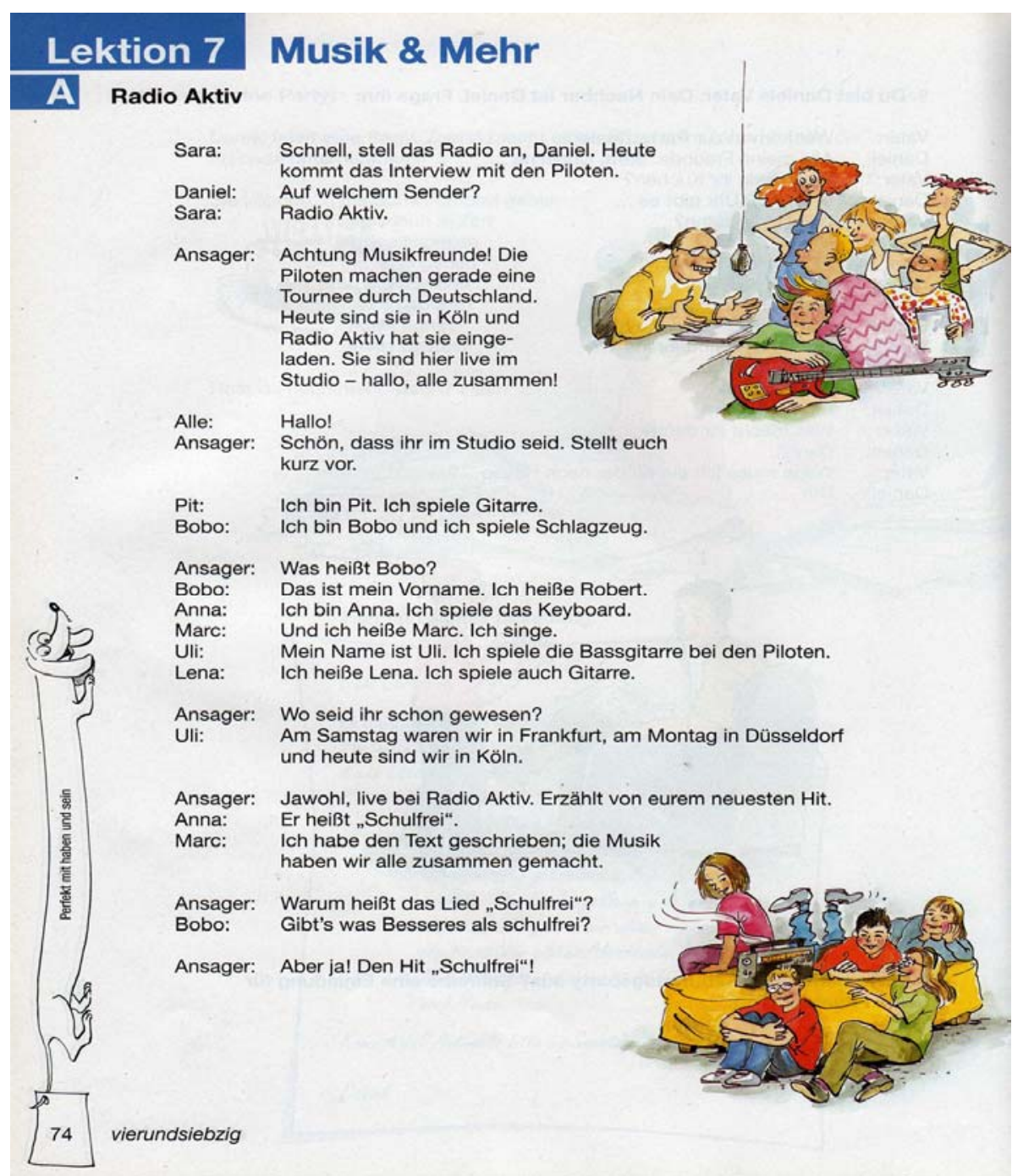

Figura 1: É o início da unidade 7, “Música e algo mais”. A primeira atividade p.74 envolve uma entrevista no rádio com a banda fictícia "Piloten", que estouraram com o sucesso "Schulfrei" - algo como "Sem escola" ou "Livres da aula". Nessa entrevista os integrantes da banda se apresentam falando seu nome e o instrumento que tocam. Falam também dos últimos locais que visitaram em sua turnê. No canto inferior esquerdo, junto ao número da página, vemos os objetivos de aprendizado dessa atividade, que são o passado perfeito com os verbos auxiliares ter e estar/ser (Perfekt mit haben und sein). 
Assim que o professor conseguiu chamar a atenção novamente para si, eles escutaram a entrevista uma vez, depois da qual ninguém parecia ter entendido muita coisa. Escutaram-na novamente, sempre fazendo pausas estratégicas para explicações. Após as explicações, ouviu-se a entrevista uma última vez. O professor, então, perguntou quem gostaria de ser o entrevistador, Anna, Bobo etc. para as crianças, finalmente, interpretarem a entrevista elas mesmas. Não se falou muito mais dessa entrevista, que também não chegou a ser tratada mais tarde como gênero; passou-se diretamente para a página 75 .

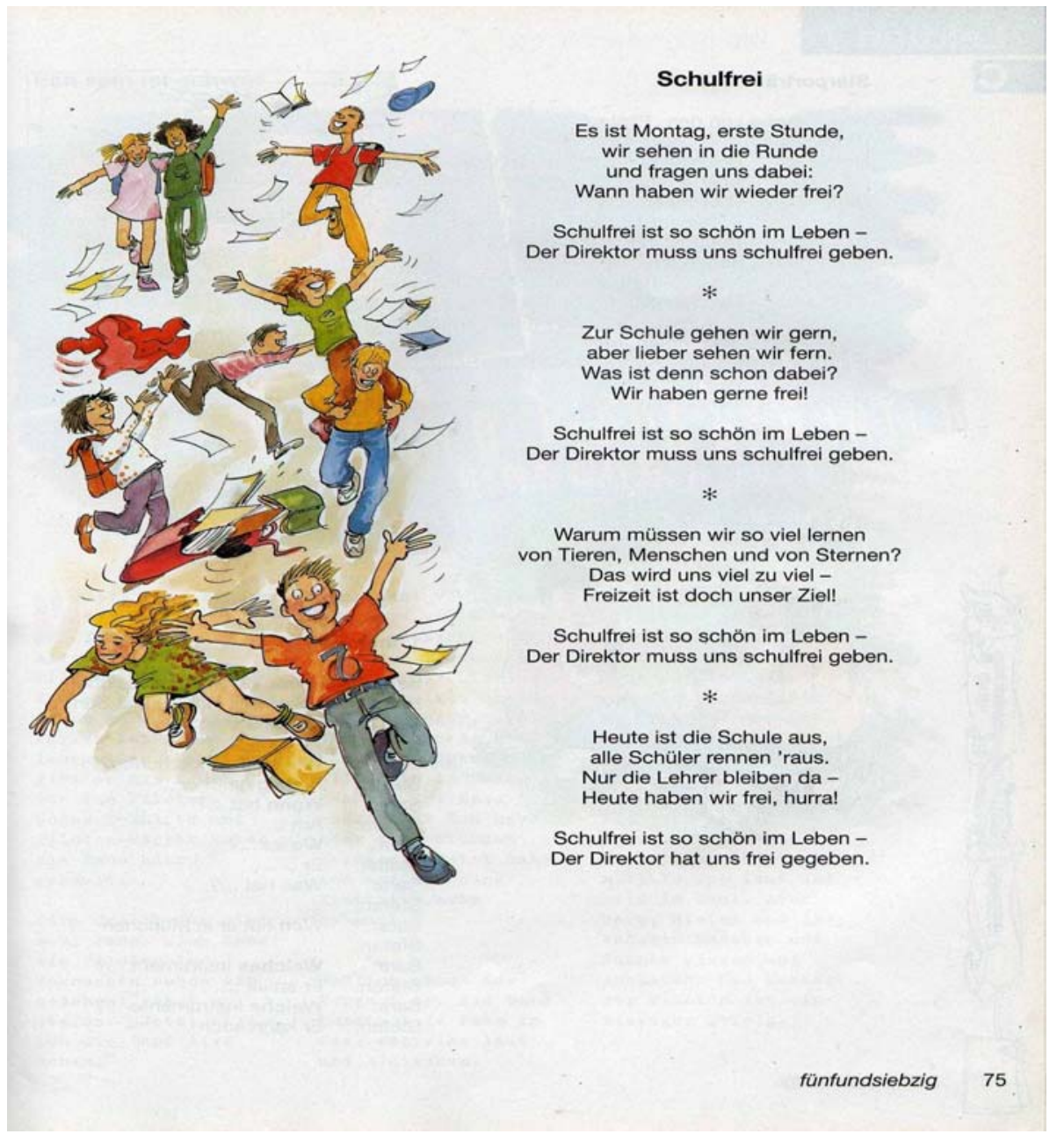

Figura Temos aqui a letra da canção de sucesso da banda. A música trata de uma 2: p.75 segunda-feira em que os alunos se encontram na primeira aula e se olham, pensando em quando vão ter tempo livre de novo. Fala de exigir ao diretor da escola que os libere da aula, para irem para casa assistir TV. Repentinamente, na última estrofe, fala que nesse dia a escola acaba e que apenas os professores ficam na escola: os pedidos das crianças foram atendidos e o diretor as liberou das aulas. 
O professor mostrou, então, aos alunos que eles iriam escutar a música dos “Piloten” e perguntou a eles se estavam lembrados de outra banda que já apareceu no primeiro volume do livro didático. As crianças responderam que sim, que estavam lembradas da música e algumas, que aparentemente eram tidas como as crianças "bagunceiras" da sala, perguntam porque eles não escutavam uma música da Fergie ou de Bob Marley, músicos que pareciam realmente agradar as crianças dessa turma e fazer parte de sua vida. O professor ignorou esses comentários, falando que eles iriam se concentrar na música dos “Piloten”, que “é muito legal”.

A música foi ouvida 3 vezes, assim como a entrevista, e surgiu um momento de grande estranhamento na sala, pois tudo na canção parecia não combinar: o ritmo não era o de uma banda pop, as vozes pareciam ser de um coral de igreja e a letra, por mais que realmente envolvesse uma temática adolescente, não o fazia de maneira coerente ou realista, impedindo que os alunos considerassem aquela música como um produto cultural real, que merecesse atenção e crítica. Na última vez que a música foi reproduzida no aparelho de som, o professor pediu aos alunos que cantassem junto e então o momento de estranhamento se acentuou, pois nenhuma criança cantou junto e apenas o professor cantou e dançou na frente da sala. Assim que a escuta acabou, o professor pediu às crianças que se sentassem em duplas para realizar as tarefas do livro de exercícios referentes à entrevista e à música. As tarefas desenvolvidas foram as descritas nas figuras 3 e 4 (p. 14 e 15): 


\section{Lektion 7}

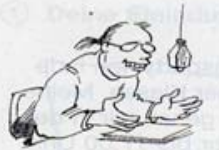

(1) Verbinde die passenden Satzhälften:

Sprecher: Liebe Fans! Gerade waren „Die Piloten“ im Studio. Sie haben von ihrer Tournee erzählt. Noch einmal die Informationen:

\begin{tabular}{|l|l|}
\hline Die bekannten Piloten & alle zusammen gemacht. \\
Heute sind & heißt Schulfrei. \\
Am Samstag waren die & sie in Köln gewesen. \\
Am Montag waren & den neuen Hit geschrieben. \\
Der neue Hit der Band & alle gern gehabt. \\
Marc hat & waren heute im Studio. \\
Die Musik haben & Musiker in Frankfurt. \\
Schulfrei haben die Musiker & sie in Düsseldorf. \\
\hline
\end{tabular}

(2) Hörverständnis

\section{Liebe Fans!}

Heute waren die "Blauen Nelken“ im Studio. Die bekannte Band hat einen neuen Hit. Er heißt „Nur du“. Radio Aktiv hat ihn heute gespielt. Schon 15000 Fans haben die CD gekauft.

Die Band macht eine Tournee durch Deutschland. Am Montag waren die Musiker in München. Am Dienstag waren sie in Gießen. Am Mittwoch haben sie Pause gemacht. Alle Musiker sind ins Schwimmbad gegangen.

Gestern waren sie in Siegen und heute sind sie in Köln gewesen. Am Abend geben sie ein großes Konzert in der Kölnarena.

Trage ein:

Name der Band:

Neuer Hit:

Verkaufte CDs:

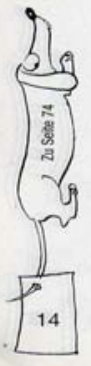

Wo waren die Musiker ..

am Montag?

am Dienstag?

am Mittwoch?

gestern?

heute?

Wo findet das Konzert heute statt?

Figura

No exercício número 1 o aluno deve conectar os começos das frases com

3: p.14 seus fins. Para isso, deve mostrar que sabe que verbos formam o passado com o auxiliar ser/estar e quais com o verbo ter. O contexto das frases não ajuda o aluno a conseguir realizar a tarefa sem ter esse conhecimento.

No segundo exercício, o aluno é confrontado com um texto que parece ter saído do blog de alguma rádio, pelo qual se é informado de que a banda "Blaue Nelken" (Cravos azuis) esteve no estúdio e contou sobre a sua última turnê e seus sucessos. O aluno deve então fazer uma espécie de ficha com as informações sobre a banda que encontra no texto. 


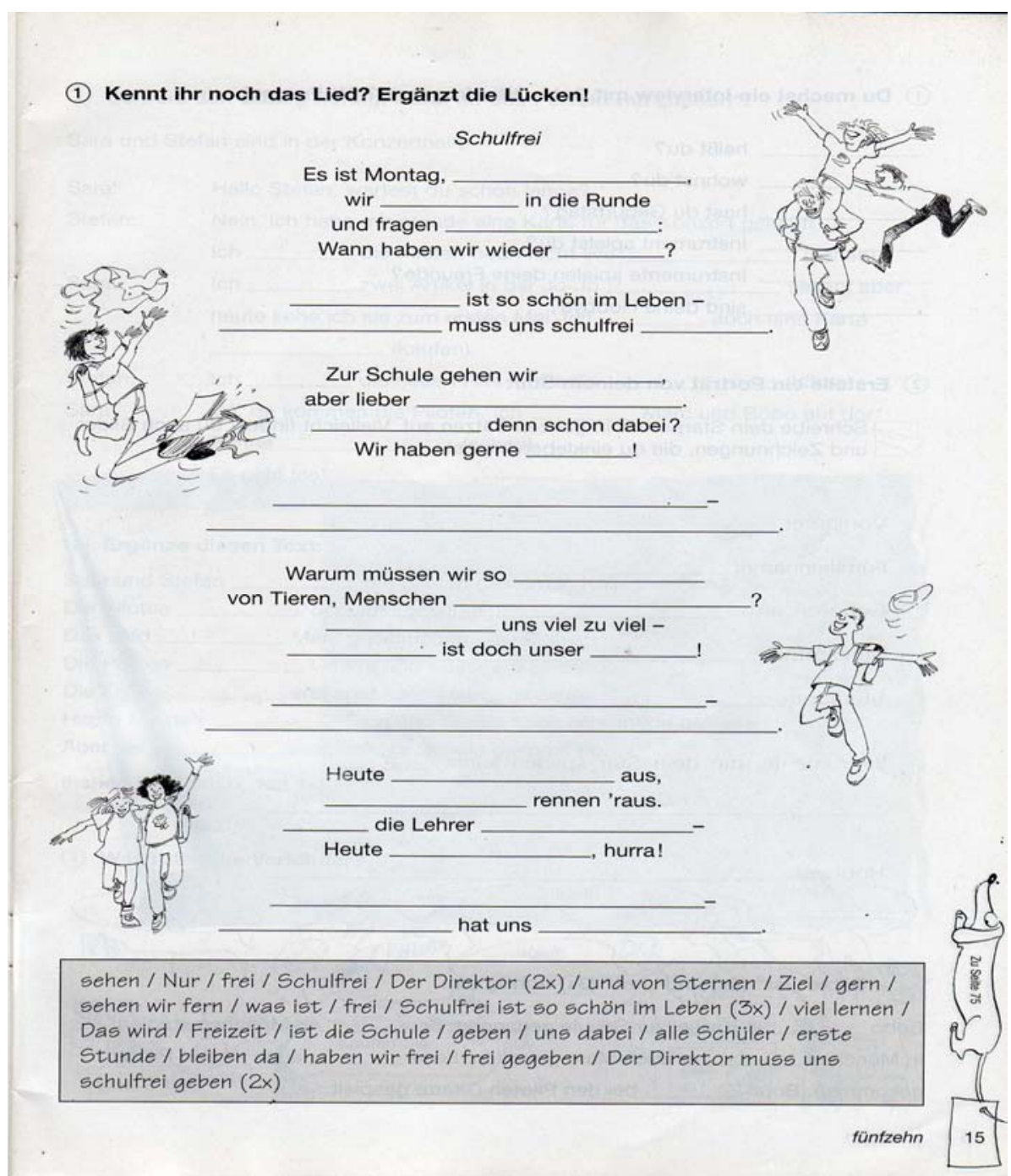

Figura Aqui, na página 15 do livro de exercícios, temos uma cópia da letra da 4, p.15 música dos “Piloten”, com lacunas. O aluno deve preencher as lacunas com ajuda do quadro abaixo da letra, no qual estão todas as partes retiradas do texto, embaralhadas. Ele não deve fazer isso escutando a música.

Algumas duplas conseguiram resolver as atividades propostas em pouco tempo, e quando foram entregá-las ao professor para serem corrigidas, ele respondeu admirado com um “já?!”. Essas duplas foram então mandadas de volta aos seus lugares para reverem o que tinham feito e conferirem se não havia, realmente, erros. Muitas crianças começaram a se distrair ou fazer outras coisas, e outras não chegaram a compreender o que deviam fazer, pois a tarefa não fora explicada oralmente. O horário da aula acabou e aqueles que não tinham conseguido terminar tudo deviam fazê-lo em casa. O jogo anunciado no quadro não chegou a ser feito. 
$\mathrm{Na}$ aula seguinte, o professor iniciou as atividades escrevendo novamente no quadro o que seria feito naquele dia. Ele pediu aos alunos que relembrassem o que tinham feito na aula anterior e assim eles viram que deviam começar pela correção da tarefa de casa. Como muitos não a tinham feito, o professor mencionou a nota de participação de cada um, que dependia desse tipo de envolvimento, e que infelizmente estava ficando prejudicada.

Depois dessa pequena introdução, o professor pediu aos alunos que pegassem seus livros de exercícios e que os abrissem na página 14. Enquanto isso, ele pegou o cd e o colocou no aparelho de som, como na aula anterior.

Quando a música foi tocada (esse exercício foi corrigido primeiro), alguns alunos até ficaram mais à vontade e cantaram algumas partes junto com o cd, mas muitos outros ficaram dando risadinhas tanto sobre a letra quanto sobre as imagens do livro. No momento de conferir se os alunos realmente tinham conseguido preencher as lacunas, porém, pareceu que nenhum deles se sentia muito à vontade para se expor a toda a sala.

Foi o professor que acabou dando todas as respostas, sempre depois de esperar alguns segundos ao início de cada nova lacuna para ver ser algum aluno se pronunciava. Todas as perguntas das crianças sobre vocabulário ou expressões utilizadas na música foram respondidas em português.

Depois de haver concluído a correção dessa atividade e também das da página anterior no livro, o professor pediu aos alunos que fizessem a primeira atividade da página 16 do livro de exercícios (figura 5). 
(1) Du machst ein Interview mit Bobo. Wie fragst du? (W-Fragen)

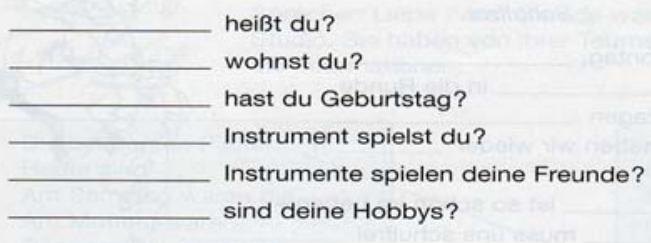

(2) Erstelle ein Porträt von deinem Star:

Schreibe dein Starporträt in ganzen Sätzen auf. Vielleicht findest du auch Bilder und Zeichnungen, die du einkleben kannst.

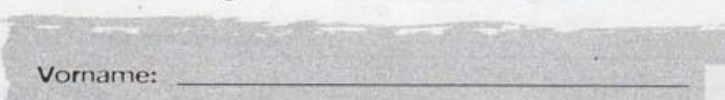

Familienname:

Geboren am:

Schulort:

Studium:

Instrumente, die dein Star spielen kann:

Hobbys:

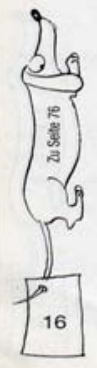

Setze „ist" $(2 x)$ und „hat" $(3 x)$ richtig ein:

Bobo __ in Kassel zur Schule gegangen. Er

In München __ er auch Marc getroffen. Lena

in München studiert.

gekommen. Bobo

bei den Piloten Gitarre gespielt.

sechzehn

Figura Na primeira atividade desta página 16 o aluno deve completar as perguntas

5, p. 16 de uma entrevista com Bobo, um integrante da banda do livro, com os pronomes interrogativos (as famosas W-Fragen do alemão). Para isso, ele deve usar o livro-texto aberto na página 76 (figura 6).

$\mathrm{Na}$ segunda atividade, eles devem elaborar um perfil de um astro que considerem interessante. Devem responder às mesmas perguntas colocadas a Bobo, na página 76 do livro-texto (figura 6).

Para realizar essas tarefas, os alunos podiam se juntar a outro e sentar no chão. Muitos realmente usaram esse espaço, mas, mesmo apesar de poderem trabalhar em grupos, muitos demonstraram dificuldades em realizar a tarefa proposta, uma vez que se esqueceram de que deviam consultar o livro-texto para isso. $O$ professor tinha mencionado esse fato brevemente no momento de explicar oralmente o que devia ser feito. Depois de alguns minutos o professor pediu aos alunos que voltassem a seus 
lugares para corrigirem as tarefas. A correção foi feita no quadro, relacionando os pronomes interrogativos aos casos da língua alemã (nominativo, acusativo, dativo; o genitivo ainda não foi ensinado).

Após terminar a correção, que correu de maneira um pouco conturbada, uma vez que as crianças preferiam tentar adivinhar as respostas em vez de escutar as explicações gramaticais, o professor fez algumas indicações sobre o trabalho que iria ser realizado na aula seguinte. Eles iriam à sala de computação para responder às questões da segunda atividade da página 16 do livro de atividades (figura 5). O professor explicou que tipo de comportamento é apropriado para aquele ambiente e pediu aos alunos que já fossem pensando em que artista iam escolher para realizar a atividade. Depois de suas explicações, os alunos que não tinham mais tarefas em aberto puderam realmente brincar de memória (um jogo que foi elaborado com fins didáticos: eles devem associar imagens de instrumentos aos seus nomes e gêneros, que nas aulas de alemão como língua estrangeira são muitas vezes associadas a cores, que podem ser encontradas no fundo das imagens). Enquanto os alunos jogavam o jogo da memória, o professor corrigia os cadernos dos alunos para poder lançar as notas de participação.

$\mathrm{Na}$ aula em que foram à sala de computação, notou-se, principalmente, que os alunos, apesar de viverem rodeados de tecnologia, não têm muita intimidade com mecanismos de busca de informações na Internet. Eles digitaram o nome de seu artista escolhido no campo de busca do google e entraram na primeira página proposta pelo mecanismo. Dessa maneira, muitos alunos não conseguiram preencher os campos pedidos pelo perfil no livro, uma vez que o gênero que encontraram ali não era o mesmo que encontram na Internet - o que a internet propõe são em sua maioria blogs com críticas musicais, links para fotos e downloads de cds, além de sites de fofoca que dificilmente falarão da formação acadêmica de um artista.

Ao se confrontar com esses problemas, aparentemente não previstos, o professor sentou-se ao lado dos alunos que o chamaram e foi buscando para eles as informações. Ele as ditou para que o aluno as anotasse no livro de exercícios (é necessário ter em conta que grande maioria dos sítios acessados pelas crianças não é em alemão).

Após aproximadamente quinze minutos, muitos dos alunos já não estavam mais concentrados no trabalho da aula, mas visitando sítios de seu interesse autêntico. A aula continuou silenciosamente até o sinal bater. 


\section{A Proposta}

Após haver apresentado as aulas observadas, gostaria de propor uma outra maneira de trabalhar no mesmo contexto, com os mesmos alunos, na mesma escola e com o mesmo material didático, para apresentar possibilidades realistas de mudanças. Para melhor mostrar ao leitor a maneira a ser trabalhada com os alunos, vou expor aqui um plano de aula, depois mostrando o material extra-livro a ser usado neste plano e fazendo comentários para estabelecer um diálogo entre a proposta e o que foi analisado.

\section{O Plano de Aula}

Antes de apresentar o plano em sua completude ao leitor, quero ainda comentar que esse plano se refere aos 200 minutos utilizados pelo professor cujas aulas foram descritas, propondo uma maior continuidade dentro das atividades.

\begin{tabular}{|c|c|c|c|c|c|}
\hline \multirow{2}{*}{ Fases } & \multicolumn{2}{|c|}{$\begin{array}{c}\text { Desenvolvimento } \\
\text { Metodológico }\end{array}$} & \multirow{2}{*}{$\begin{array}{l}\text { Material } \\
\text { utilizado }\end{array}$} & \multirow{2}{*}{$\begin{array}{l}\text { Forma } \\
\text { social }\end{array}$} & \multirow{2}{*}{ Tempo } \\
\hline & $\begin{array}{ll}\text { Papel do } & \text { do } \\
\text { professor } & \\
\end{array}$ & $\begin{array}{l}\text { Expectativa do papel do } \\
\text { aluno }\end{array}$ & & & \\
\hline $\begin{array}{l}\text { Warm } \\
\text { up }\end{array}$ & $\begin{array}{l}\text { O professor } \\
\text { deve propor um } \\
\text { brainstorming } \\
\text { sobre o que é } \\
\text { música para os } \\
\text { alunos. Para } \\
\text { isso, ele pode } \\
\text { guiar a idéias } \\
\text { dos alunos } \\
\text { propondo } \\
\text { alguns sub- } \\
\text { campos como: } \\
\text { tema, letras, } \\
\text { sentimentos }\end{array}$ & $\begin{array}{l}\text { Os alunos devem expressar } \\
\text { livremente o que acreditam } \\
\text { estar vinculado à música. } \\
\text { Eles podem fazer isso tanto } \\
\text { em português quanto em } \\
\text { alemão (sugiro que o } \\
\text { professor escreva apenas em } \\
\text { alemão no quadro, para já } \\
\text { poder apresentar palavras } \\
\text { novas). Imagino que os } \\
\text { alunos falem coisas bastante } \\
\text { variadas, vinculadas tanto à } \\
\text { forma quanto aos conteúdos } \\
\text { de faixas de seu } \\
\text { conhecimento } \\
\text { (provavelmente música pop, } \\
\text { mpb etc.) }\end{array}$ & quadro & plenário & $\begin{array}{l}5^{\prime} \\
10^{\prime}\end{array}$ \\
\hline
\end{tabular}




\begin{tabular}{|c|c|c|c|c|c|}
\hline 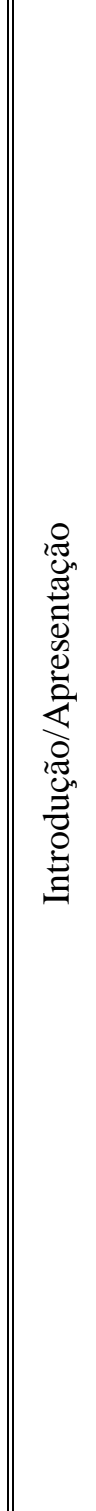 & $\begin{array}{l}\text { Depois de haver } \\
\text { dado aos alunos a } \\
\text { oportunidade de } \\
\text { expressarem o que } \\
\text { acreditam ser } \\
\text { música, o professor } \\
\text { deve apresentar a } \\
\text { eles os três textos a } \\
\text { serem tratados na } \\
\text { aula: um compêndio } \\
\text { de poemas de } \\
\text { Johann Wolfgang } \\
\text { von Goethe, o } \\
\text { sucesso Perfekte } \\
\text { Welle, da banda } \\
\text { alemã Juli e o } \\
\text { sucesso Como uma } \\
\text { onda, do brasileiro } \\
\text { Lulu Santos. Os três } \\
\text { textos devem ser } \\
\text { ouvidos em cd. } \\
\text { Entre a apresentação } \\
\text { de um texto e outro, } \\
\text { os alunos devem } \\
\text { falar suas primeiras } \\
\text { impressões, que } \\
\text { serão anotadas no } \\
\text { quadro, perto do } \\
\text { primeiro } \\
\text { brainstorming. }\end{array}$ & $\begin{array}{l}\text { Os alunos devem } \\
\text { ouvir atentamente } \\
\text { e reparar nas } \\
\text { diferenças entre } \\
\text { um texto e outro, } \\
\text { devem se dar } \\
\text { conta de seus } \\
\text { contextos de } \\
\text { produção, de seus } \\
\text { propósitos etc. } \\
\text { Eles também } \\
\text { podem expressar } \\
\text { o que sentem em } \\
\text { relação a cada } \\
\text { um, como por } \\
\text { exemplo, } \\
\text { animação ou } \\
\text { incompreensão. }\end{array}$ & $\begin{array}{l}\text { quadro, } \\
\text { apare-lho } \\
\text { de som }\end{array}$ & Plenário & $15^{\prime}$ \\
\hline
\end{tabular}




\begin{tabular}{|c|c|c|c|c|c|}
\hline 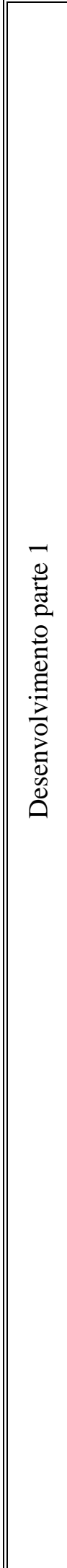 & $\begin{array}{l}\text { Depois de haver entregue aos } \\
\text { alunos seus materiais, o } \\
\text { professor explica a eles o que } \\
\text { devem fazer. As tarefas, que } \\
\text { estão anotadas junto em uma } \\
\text { folha dentro do pacote de } \\
\text { materiais, são: } \\
\text { 1) ler o texto com calma e } \\
\text { compreender sua mensagem, } \\
\text { respondendo a perguntas } \\
\text { gerais sobre o funcionamento } \\
\text { do texto, como p.e. de que } \\
\text { tema ele trata. Fazer anotações } \\
\text { sobre o papel do texto, que } \\
\text { depois possam ajudar outros a } \\
\text { entendê-lo (vocabulário, } \\
\text { idéias); } \\
\text { *O grupo que trabalhar com o } \\
\text { artista brasileiro deverá } \\
\text { explicar a música, sem traduzi- } \\
\text { la, a um falante de alemão. } \\
\text { Isso quer dizer que devem } \\
\text { elaborar um pequeno texto no } \\
\text { formato de uma resenha sobre } \\
\text { a música; } \\
\text { 2) encontrar entre } 5 \text { e } 10 \\
\text { possíveis títulos para o texto; } \\
\text { 3) pegar uma das fotos dadas } \\
\text { do autor e fazer um } \\
\text { brainstorming sobre ele, } \\
\text { baseando-se nas atividades } \\
\text { propostas nas páginas } 74 \text { e } 76 \\
\text { do livro-texto, mas } \\
\text { adicionando outras } \\
\text { informações interessantes; } \\
\text { 4) fazer uma entrevista com o } \\
\text { autor, baseando-se no } \\
\text { brainstorming. } \\
\text { 5) elaborar um cartaz que } \\
\text { exponha os materiais usados e } \\
\text { criados (texto comentado, foto } \\
\text { com brainstorming e } \\
\text { entrevista) }\end{array}$ & $\begin{array}{l}\text { Os alunos devem } \\
\text { colocar suas } \\
\text { dúvidas quanto } \\
\text { ao } \\
\text { desenvolvimento } \\
\text { desse pequeno } \\
\text { projeto e se } \\
\text { organizar para } \\
\text { conseguir } \\
\text { realizar todas as } \\
\text { fases no tempo } \\
\text { proposto. Vale } \\
\text { lembrar que cada } \\
\text { um tem suas } \\
\text { habilidades mais } \\
\text { desenvoltas, que } \\
\text { devem encontrar } \\
\text { espaço dentro da } \\
\text { execução do } \\
\text { projeto }\end{array}$ & $\begin{array}{l}\text { Carto- } \\
\text { lina, } \\
\text { cola e } \\
\text { tesou-ra }\end{array}$ & $\begin{array}{l}\text { Grupos } \\
\text { reunidos, } \\
\text { no chão ou } \\
\text { em mesas } \\
\text { grandes }\end{array}$ & $\begin{array}{l}80^{\prime} \text { a } \\
100^{\prime}\end{array}$ \\
\hline
\end{tabular}




\begin{tabular}{|c|c|c|c|c|c|}
\hline 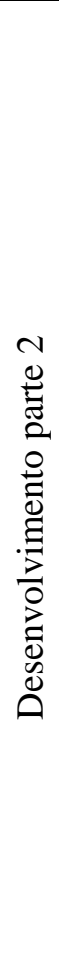 & $\begin{array}{l}\text { Assessoramento } \\
\text { O professor deve pedir aos } \\
\text { alunos que exponham seus } \\
\text { cartazes de maneira acessível } \\
\text { dentro da sala. }\end{array}$ & $\begin{array}{l}\text { Os alunos devem } \\
\text { encontrar uma } \\
\text { dinâmica de } \\
\text { trabalho e } \\
\text { desenvolver as } \\
\text { atividades } \\
\text { propostas, } \\
\text { sempre podendo } \\
\text { voltar-se ao } \\
\text { professor para } \\
\text { pedir sugestões } \\
\text { ou ajuda. } \\
\text { Os alunos devem } \\
\text { pensar sobre qual } \\
\text { parte da sala se } \\
\text { adequa melhor } \\
\text { para a exposição } \\
\text { do seu trabalho }\end{array}$ & & & \\
\hline 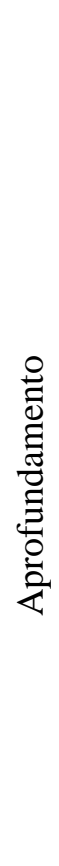 & $\begin{array}{l}\text { Quando isso tiver sido feito, o } \\
\text { professor deve propor que } \\
\text { cada aluno pegue seu caderno } \\
\text { e elabore um perfil (neste } \\
\text { ponto ele pode trazer } \\
\text { exemplos de revistas) de cada } \\
\text { autor (seguindo, ainda, o } \\
\text { modelo da proposta na página } \\
16 \text { do livro de exercícios), } \\
\text { visitando os cartazes de seus } \\
\text { colegas e reestruturando as } \\
\text { informações encontradas no } \\
\text { material. }\end{array}$ & $\begin{array}{l}\text { Os alunos devem } \\
\text { visitar o material } \\
\text { produzidos pelo } \\
\text { seu grupo e os } \\
\text { cartazes de seus } \\
\text { colegas, lendo } \\
\text { bem as } \\
\text { informações } \\
\text { expostas e } \\
\text { reestruturando-as } \\
\text { para um perfil } \\
\text { nos padrões de } \\
\text { revistas para } \\
\text { adolescentes } \\
\text { (Capricho, } \\
\text { Bravo- uma } \\
\text { revista alemã) }\end{array}$ & $\begin{array}{l}\text { Caderno, } \\
\text { cartazes }\end{array}$ & $\begin{array}{l}\text { Trabalho } \\
\text { autônomo }\end{array}$ & $20^{\prime}$ \\
\hline
\end{tabular}

Além de seguir tal plano de aula, parece-me interessante propor às crianças uma tarefa de casa em que tenham que preencher um perfil utilizando a Internet. Para tal, seria necessário explicar às crianças como utilizar mecanismos de busca como o google. Uma idéia interessante seria levar um computador para a sala junto com um projetor, para propor que eles fizessem buscas coletivas. Assim, aprenderiam coisas simples, 
como procurar informações dentro de um campo definido (como por exemplo, “procurar apenas sítios alemães”), distinguir webpages apropriadas para seus fins de outras muito complicadas etc. Esta parte, porém, deixo como módulo móvel, que seria aplicado apenas de acordo com as necessidades dos alunos.

Anexos a este texto apresento os pacotes de materiais (imagens e textos adicionais) que entregaria aos alunos para dar-lhes apoio na realização das tarefas propostas no plano. No anexo 1, as imagens para o texto de Goethe, no anexo 2 para o texto sobre a banda Juli, no anexo 3, imagens para o texto sobre Lulu Santos-

\section{Conclusão}

Em se tratando do plano de aula em geral, acredito que este tenha englobado bem as condições que hoje em dia nos são tiradas para vivenciar experiências: 1) ao dar às crianças um pacote com informações limitadas e não verbais, o plano permite que elas se envolvam com a tarefa - que em paralelo às idéias de Benjamin equivaleria à brincadeira; 2) ao pedir que produzam diálogos com os textos propostos, elas vêem-se na necessidade de expressar o que pensam de maneira implícita, dentro das perguntas e respostas de uma entrevista que não é sobre elas, mas sobre um outro indivíduo - assim, cria-se um espaço em que elas podem, à medida que atividades como estas forem se repetindo no percorrer de seu aprendizado, dar-se conta de que todo texto é permeado de opiniões e vozes; 3 ) ao propor uma atividade que envolve os alunos por quatro aulas, o plano de aula dá tempo às crianças para que possam se envolver com o assunto; 4) finalmente, ao propor poucas atividades, mas atividades ricas, o plano faz com que o aluno não se sinta sufocado pela necessidade de criar e produzir: as coordenadas são claras e levam, todas juntas, à geração de um único produto final - um cartaz.

Além disso, o plano proposto também trata cultura-linguagem de acordo com a concepção exposta no início deste relato, respeitando que cultura e linguagem andam de mãos dadas. Ao apresentar produtos culturais alemães e brasileiros, não necessariamente da mesma época, mostra-se, através da linguagem, que ambos os conceitos são vivos, modificando-se de acordo com o tempo que passa e com aqueles que colocam suas vozes neles. Torna-se, neste ponto, importante ressaltar que apesar do distanciamente do mundo infanto-juvenil que a obra de Goethe possa evocar em adultos 
que têm uma experiência de leitura desse autor, os poemas escolhidos tratam de maneira bastante simples e direta temas dominados em alemão por crianças que estão na educação bilingue. Assim, com todas suas características diferenciadas, o texto de Goethe se torna possível dentro do contexto da aula de alemão para crianças, enriquecendo a diversidade exposta. Foi, além disso, tomado o cuidado, na escolha dos textos propostos, de englobá-los dentro de um mesmo tema, bastante “universal”, que é a relação do humano com a água. Relacionar os textos, mesmo que de maneira bastante subliminar (uma vez que não é, em momento algum, falado sobre a água ou a relação que temos com ela) a um mesmo assunto, ajuda o aluno a criar um vínculo com eles, uma vez que o campo de tematizações e referências se torna muito menor, possibilitando o uso da linguagem para falar sobre o trabalho do outro, por exemplo. Assim, a aparente abertura das atividades propostas é de certa maneira fechada pelo tema, pelo vocabulário a seu usado. Isso acaba por aumentar a probabilidade de os alunos conseguirem realizar as atividades de maneira plena.

Por último, junto com o aprendizado da língua, o aluno conhece outras coisas, outros saberes que envolvem um campo de uso para essa língua; dessa maneira, lentamente, o aluno vai criando a sua imagem da cultura alemã e da própria, por meio do uso da própria linguagem.

\section{Referências}

BAKHTIN, M. (1988). Marxismo e Filosofia da Linguagem. São Paulo: Hucitec. BENJAMIN, W. (1991). Gesammelte Schriften Band III: Kritiken und Rezensionen. Frankfurt: Suhrkamp Taschenbuch Verlag (1985). Obras escolhidas vol. I: Magia e Técnica, Arte e Política -

Ensaios sobre literatura e história da cultura. São Paulo: Editora Brasiliense . (1983). Sobre alguns temas em Baudelaire. In: BENJAMIN, W.;

HORKHEIMER, W.; ADORNO, T. W.; HABERMAS, J. Textos escolhidos. São Paulo: Abril Cultural

EAGLETON, T. (2003). A Idéia de cultura. São Paulo: Unesp

HÄRTLING, P. (2002). Goethe für Kinder. Frankfurt: Insel Verlag 
LARROSA, J., SKLIAR, C. (2001). Habitantes de Babel: Políticas e poéticas da diferença. Belo Horizonte: Autêntica

LARROSA, J. (2004). Linguagem e Educação depois de Babel. Belo Horizonte:

Autêntica

MEDO, M. M., WICKE. R. E.. (1998). Wer? Wie? Was? Mega 2 (Schülerbuch und

Schülerarbeitsheft). Colônia: Gilde Verlag

SAFRANSKI, R. (2007). Romantik: Eine deutsche Affäre. Munique: Carl Hanser

Verlag

WELSCH, W. (2006). Transculturality - the puzzling form of cultures today.

Disponível em < http://www2.uni-jena.de/welsch/Papers/transcultSociety.html>

Todas as imagens utilizadas para a elaboração do material para trabalho com os textos foram encontradas no mecanismo de busca google, com as palavras-chave: Lulu Santos, Juli Musik, Juli Konzert, Juli Hülle, Goethe, Goethe Andy Warhol, mar, onda, Welle, Teich, Ufer Teich, e Fröschlein. 
ANEXO 1 - Pacote de textos e imagens para trabalho com texto do poeta alemão Johann Wolfgang von Goethe

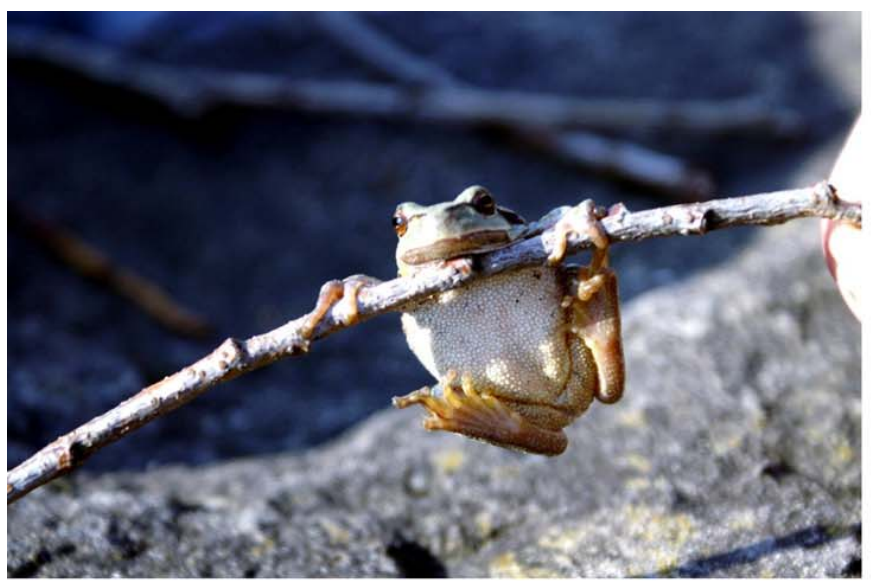

MEERESSTILLE

Tiefe Stille herrscht im Wasser,

Ohne Regung ruht das Meer,

Und bekümmert sieht der Schiffer

Glatte Fläche rings umher.

Keine Luft von keiner Seitel

Todesstille fürchterlich!

In der ungeheuern Weite

Reget keine Welle sich.

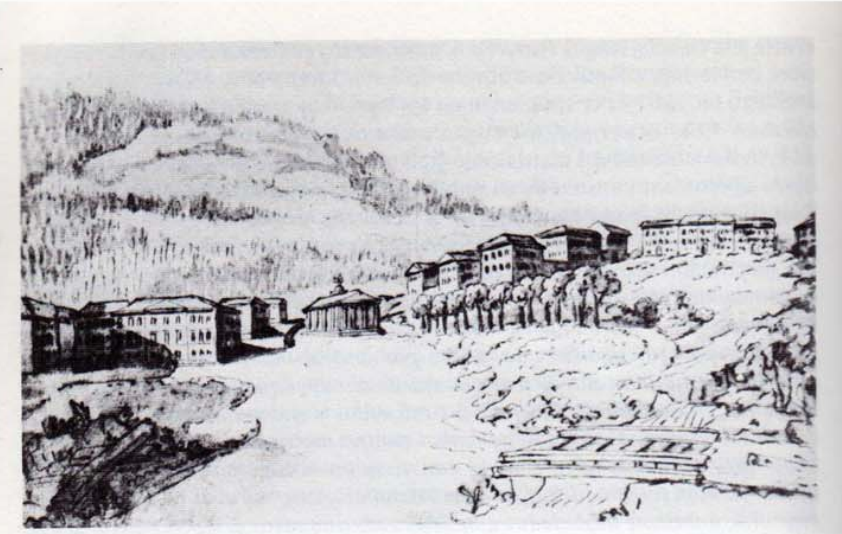

Marienbad con la «Kreuzbrunnen».

Dibujo a la aguada de Goethe, después de 1820

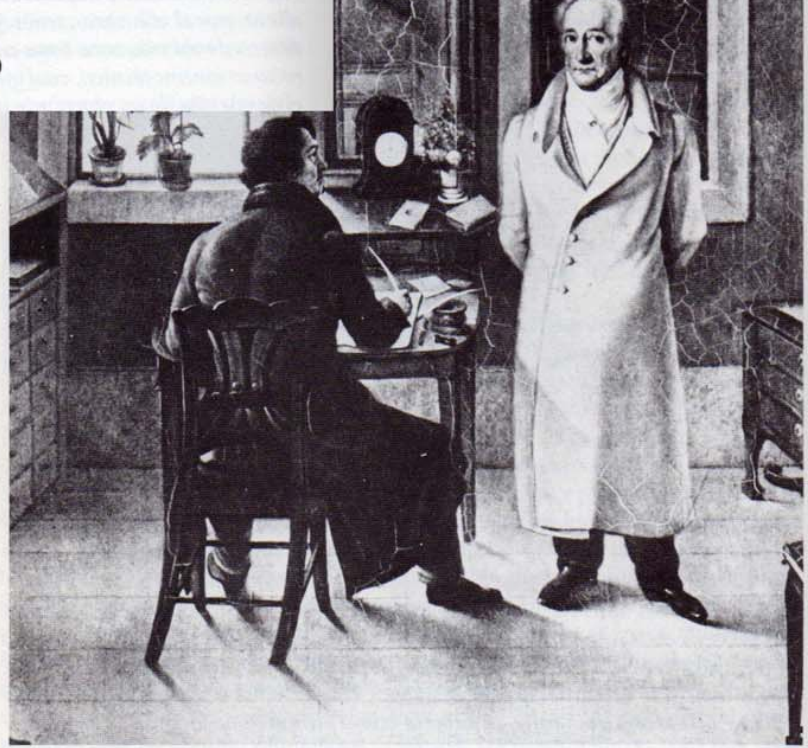

Goethe en su cuarto de trabajo

dictando a su escriba John.

Oleo de Joseph Schmeller, 1831 


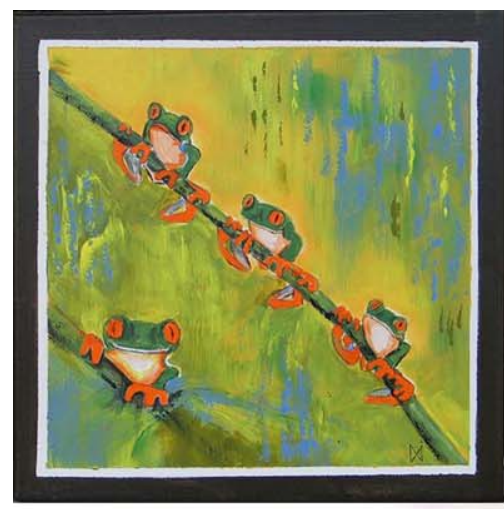

Das ist der Text der gelesen und behandelt werden soll:

Ein großer Teich war zugefroren, Die Fröschlein, in der Tiefe verloren, Durften nicht ferner quacken noch springen, Versprachen sich aber, im halben Traum, Fänden sie nur da oben Raum, Wie Nachtigallen wollten sie singen. Der Tauwind kam, das Eis zerschmolz, Nun ruderten sie und landeten stolz, Und saßen am Ufer weit und breit Und quackten wie vor alter Zeit.
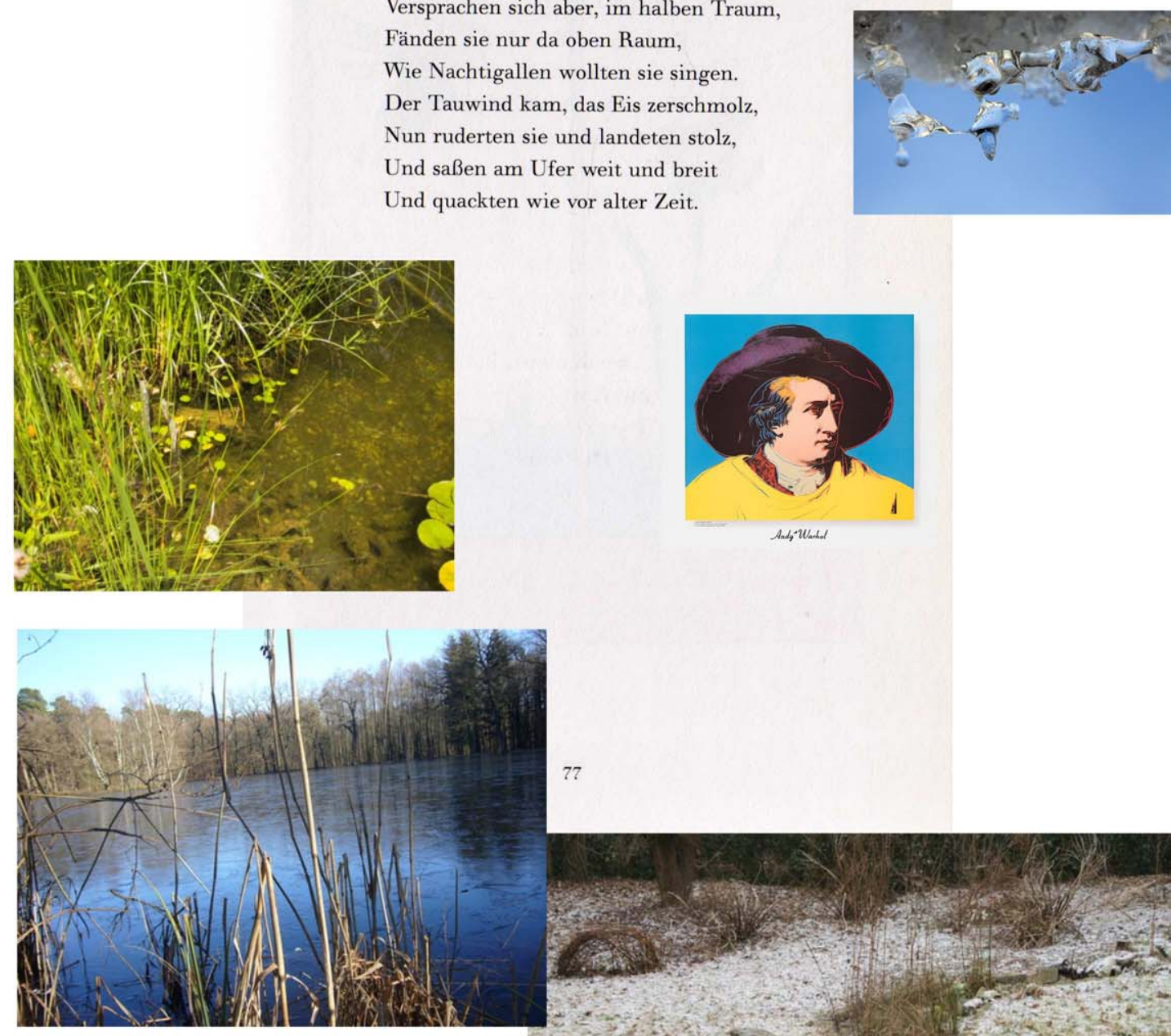

77

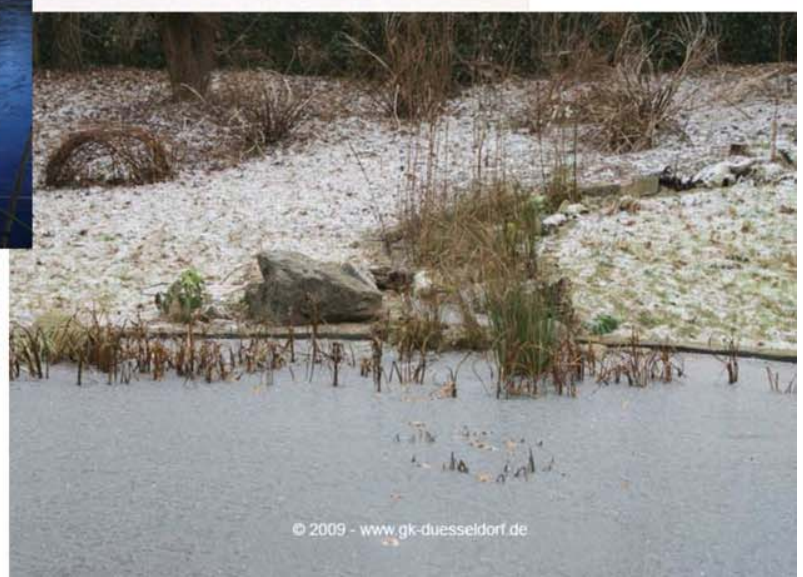


ANEXO 2 - Pacote de textos e imagens para trabalho com texto da banda alemã Juli

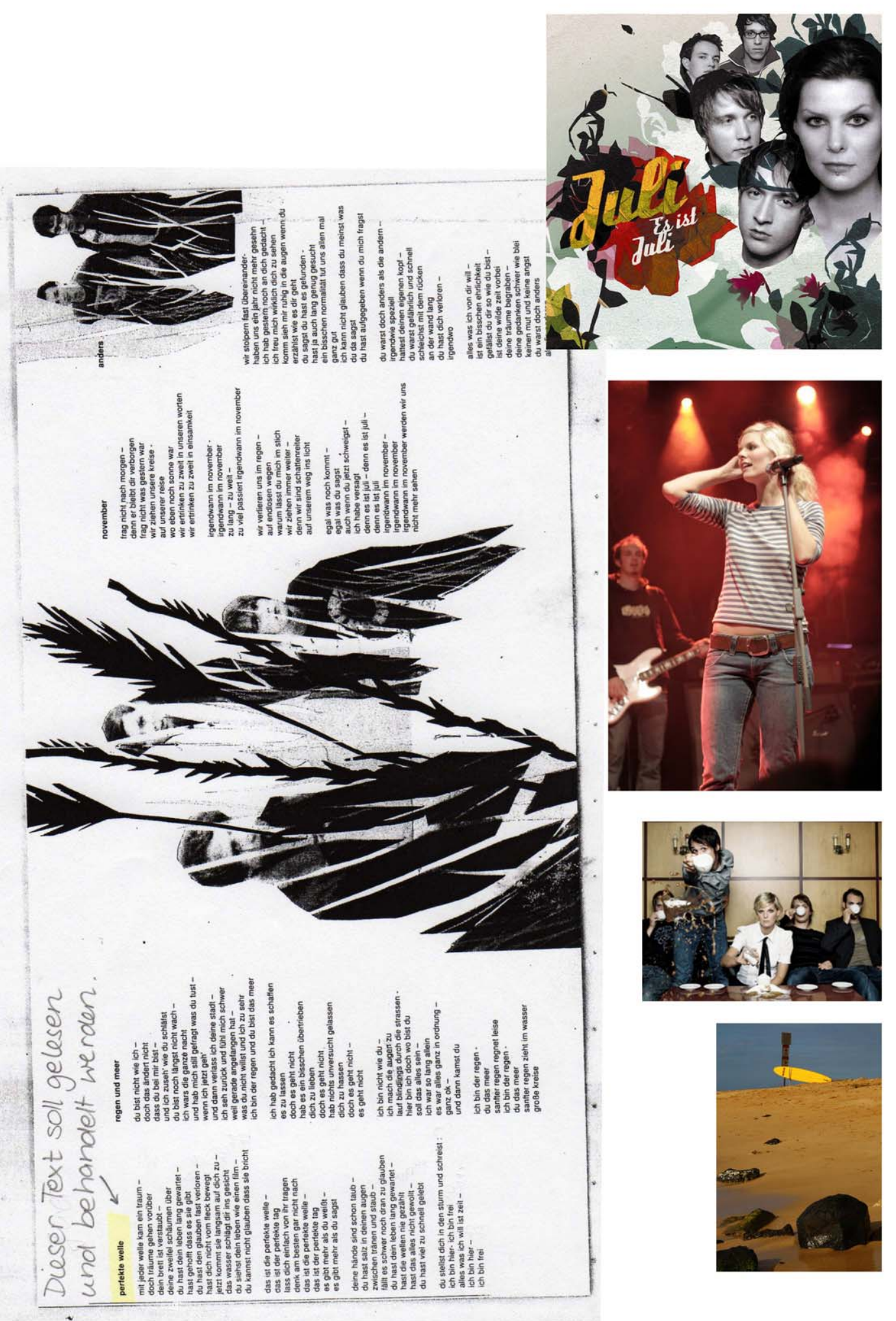



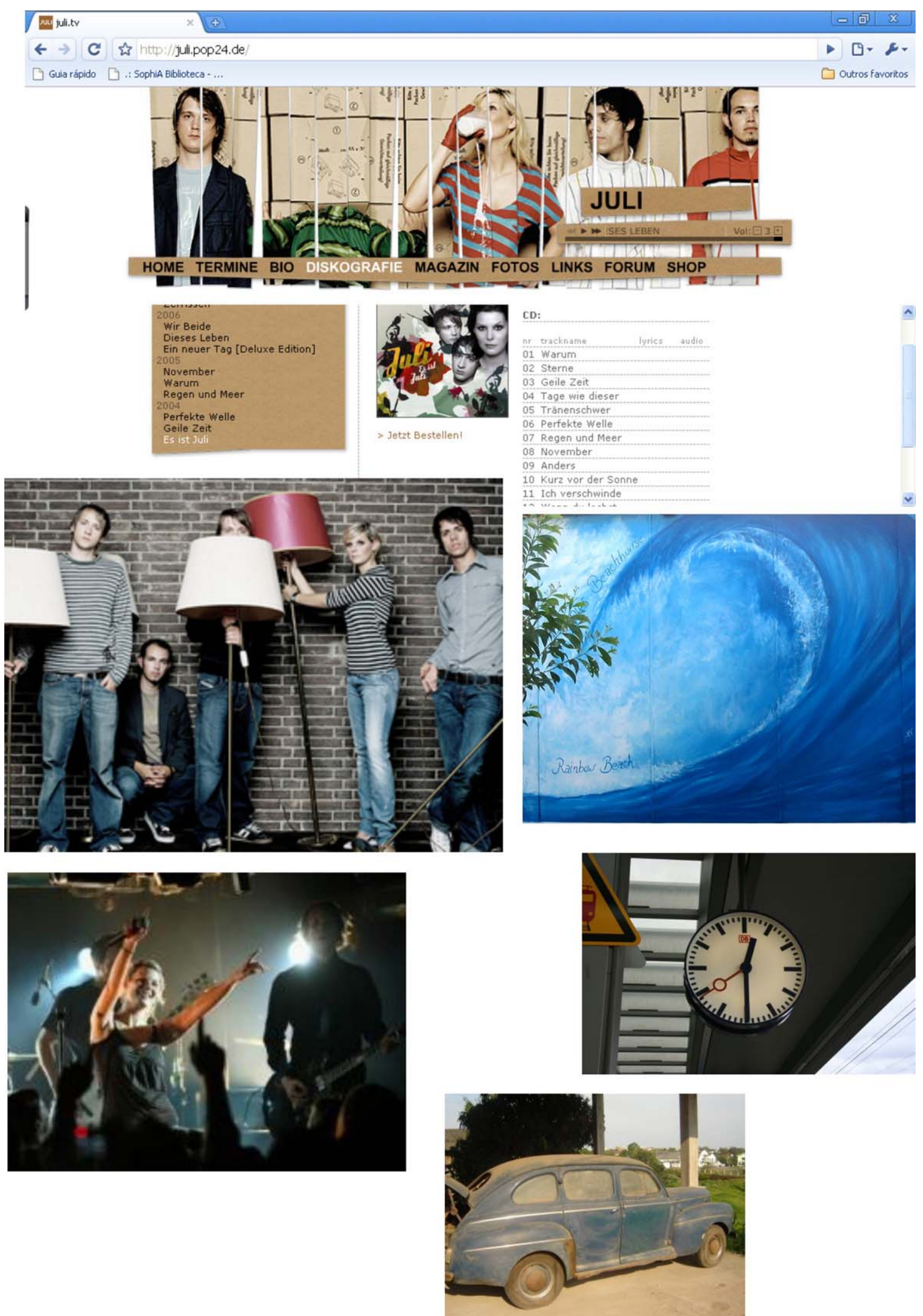
ANEXO 3 - Pacote de textos e imagens para trabalho com texto do músico brasileiro Lulu Santos
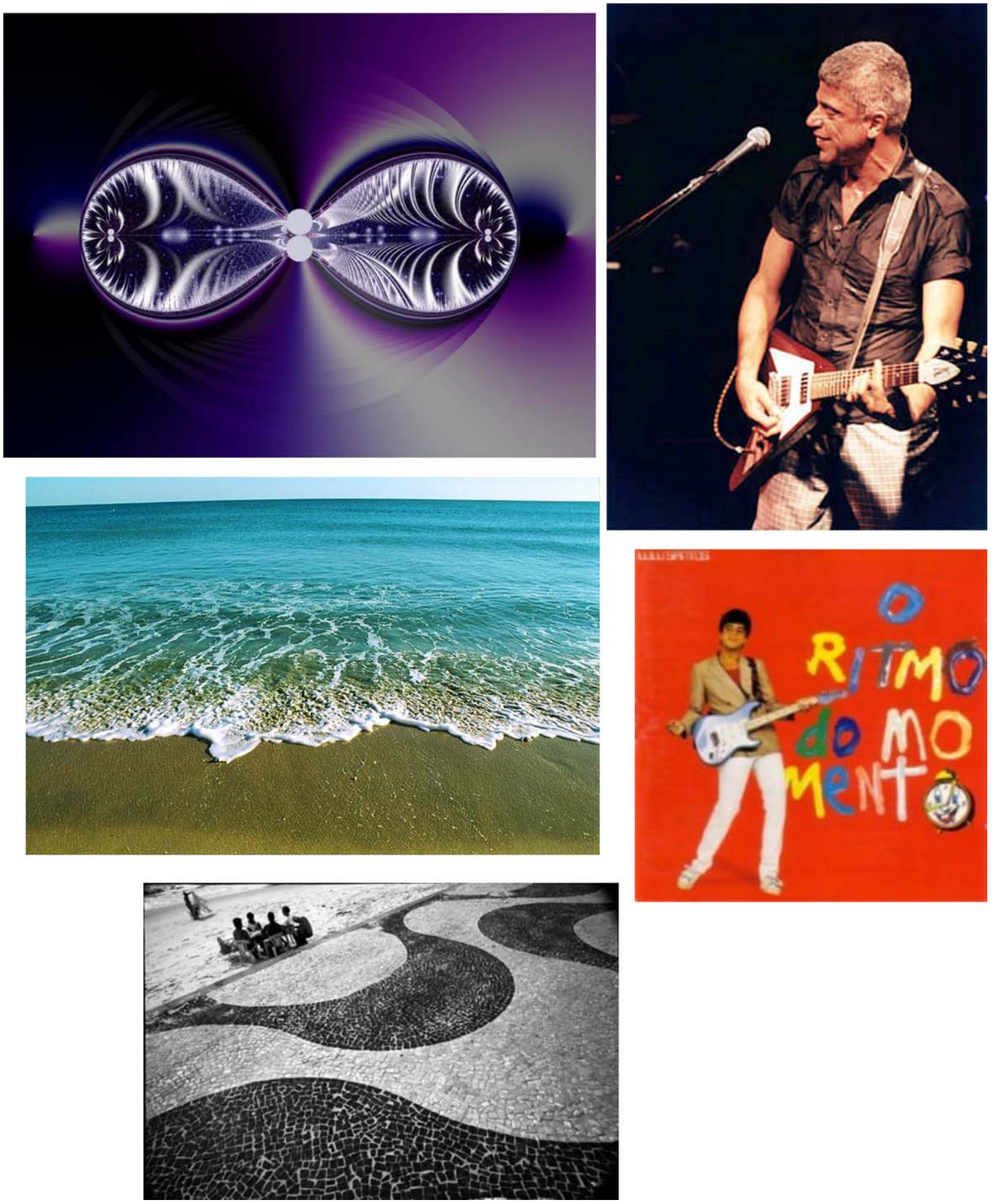

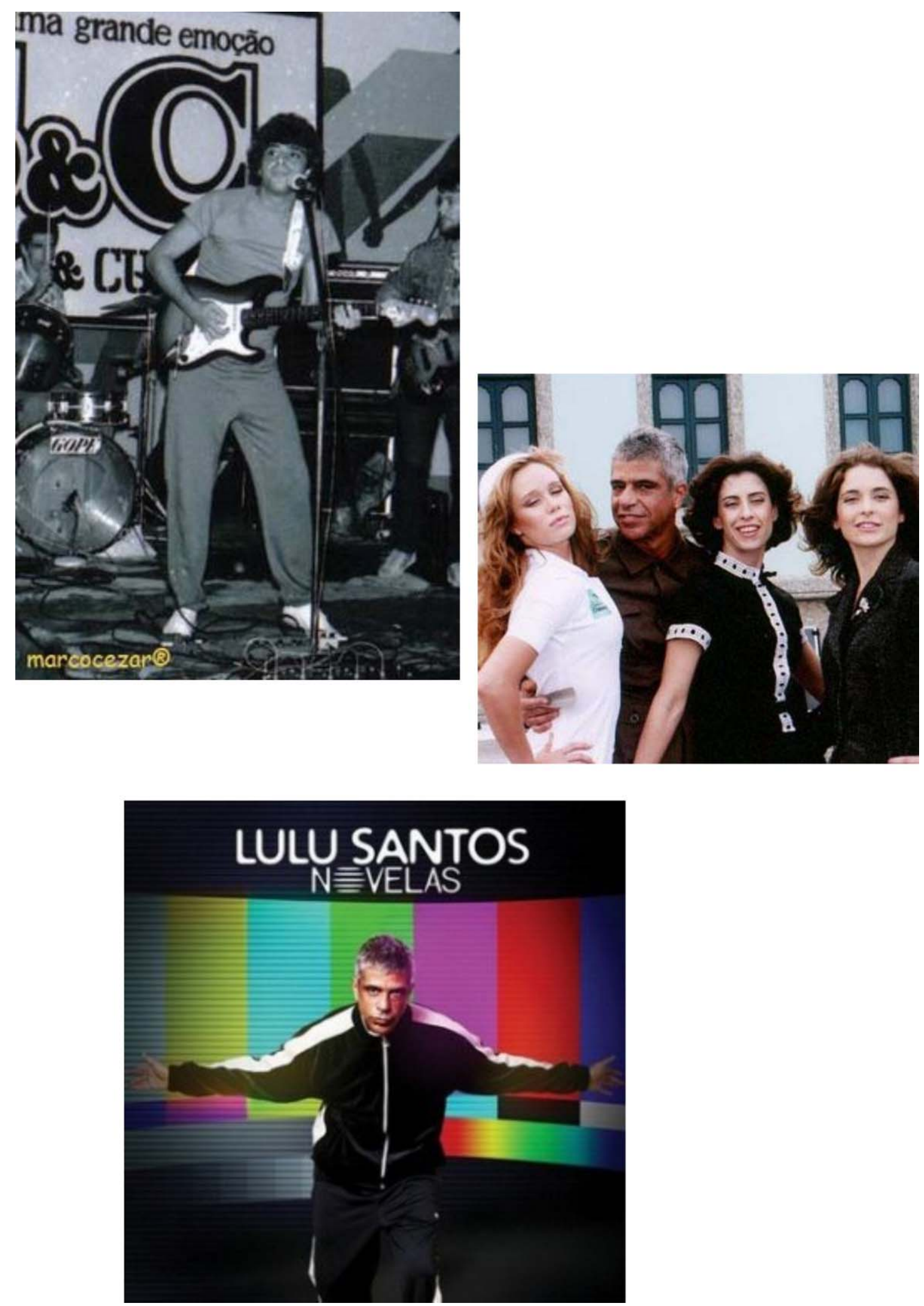